illustrating the characteristic appearances of these defects as revealed in the gamma-radiographs. The method is of particular value in the critical examination of pilot castings in indicating the soundness of the foundry technique. Since such heavy castings are usually costly, the defective regions are often cut out and afterwards welded. Further radiographic examination will reveal the soundness of the repaired section. Welded repairs of this kind may show eracks in the weld or parent metal at the edge of the weld, and Mr. Croxson pointed out that, since these cracks are tortuous and not necessarily in the same plane as the incident gamma-ray beam, great care must be taken in interpreting the radiograph. If any suspicious shadow is seen, another radiograph should be taken in one or more other directions to ensure that the presence of a crack is either confirmed or refuted. Similarly, gamma-radiography may be used for the examination of all types of welds, and the method has advantages over radiography by $\mathrm{X}$-rays when cylindrical objects are being examined : apart from the fact that the radiographic inspection of welds reveals defects, the knowledge that the method will be applied has the moral effect of making welders even more careful in their work.

In concluding, Mr. Croxson said that his experience of gamma-radiography justifies high confidence in the rapid extension of this specialized inspection technique.

\section{STALIN PRIZES FOR SCIENCE, INVENTIONS AND INDUSTRIAL TECHNOLOGY}

$\mathrm{T}$

HE following have been awarded Stalin Prizes (first class) for outstanding achievements and inventions and for improvements of the technology of industrial production in 1942. First Class prizes carry an award of 200,000 roubles each $(150,000$ roubles in the "outstanding inventions"' section):

Physics and Mathematics: P. A. Alexandrov, for studies in mathematics; P. Kapitza, for research on helium.

Technical Sciences : L. S. Leibenzon, for studies on the theory of elasticity and oil mechanics; M. A. Pavlov, for research in the technology of iron smelting.

Chemical Sciences: A. N. Nesmeyanov, for researches on metallo-organic compounds.

Geology and Geography: F. N. Krassovsky, professor of the Moscow Institute of Engineering, Geology and Cartography; P. I. Stepanov, for geological researches on the Donets Basin, summed up in his work "Geology of the U.S.S.R.".

Biology : P. M. Zhukhovsky, for his work "Botany" and for his discovery of new varieties of wheat and rye and the development from them of hybrid varieties of great economic value; V. A. Engelgardt and M. N. Lubimova, for researches on museles.

Agriculture: T. L. Lysenko, V. P. Mosolov and a group of scientific workers, for development and introduction of a method of using tops of potato tubers for cultivation.

Medical Sciences: V. N. Shevkunenkoz, lieut.general of the Medical Service, professor of the Military Medical Academy of the Red Army; A. N. Maxinenkov and A. S. Vishnevsky, professors of the same Academy, for the scientific work "Atlas of the Nervous and Venous System".
Philosophy : G. Alexandrov and B. E. Bykhovsky, M. B. Mitin, P. F. Yugin, O. Trakhtenberg and V. Asmus, for the work "History of Philosophy", in three volumes.

For many years' outstanding work in Science and Technique: M. J. Averback, First Medical Institute; A. A. Baikov, Leningrad Polytechnical Institute; B. E. Vedeneyev, Assistant Commissar for Electric Power Stations ; V.I. Vernadsky ; S. N. Dzhanashya, member of the Georgian Academy of Sciences ; B. D. Grekov, the University of Leningrad ; I. I. Meshchaninov, director of the Speech and Thought Institute, Leningrad; V. F. Mitkevich, Leningrad Polytechnical Institute; S. S. Nametkin, director of the Institute of Combustible Minerals; A. E. Forai Koshits, "Lensoviet" Leningrad Chemico-Technological Institute; N. P. Chizhevsky, K. I. Shenfer.

For outstanding Inventions and Improvements of Production Methods : N. Blokhin, chief engineer of the Central Board for Special Steels ; A. Sheremetyev, director of the Board, and a group of engineers of various works and scientific institutes, for the elaboration and introduction into industry of a new technological process of steel smelting for war industry. V. Grabin, lieut.-general of Engineering Troops; Ivanov, lieut.-general of the Artillery Engineering Service, and the assistants of the chief constructor of the Central Artillery Designing Bureau ; P. Nazarov and D. Sheffer and others, for designing new types of ordnance. A. Derkach, engineer of Works No. 695, and a group of engineers of Scientific Research Institute No. 20, for designing new types of radio equipment. Z. Yermolyeva, director of the Department of Biochemical Bacteriology, All-Union Institute of Experimental Medicine, and L. Jakobson, director of a laboratory of the Institute, for the development of a new method of early diagnosis and phagocyticprophylaxis of contagious diseases. S. Ilyushin, aircraft designer, for modifications and improvements in design of warplanes. Y. Kozhevnik, head of the central board for production of steel tubing; $\mathrm{J}$. Ossadchy, director of Works No. 703, and a group of engineers for improvement of the technology of production of mortar barrels and ammunition parts. V. Kotelnikov, head of a group of engineers of the Central Research Institute of Communications, for designing new communications equipment. J. Kotin, chief constructor of the Kirov Works; S. Makhonin, chief engineer, L. Troyanov, assistant chief constructor, F. Petrov, chief constructor of Works No. 9 ; S. Gurenko, chief constructor of Work Nos. 172, for designing a new type of artillery; N. Kuznetsov, major-general of the Artillery Engineering Service: A. Semenov, lieut.-colonel engineer, and a group of military engineers, for designing new types of arms. S. Lavochkin, aircraft designer, for modification and improvement of warplanes; H. Lurye, chief engineer of Ballbearing Works Nos. 4, 3 and 1, for organization of mass production of special bearings; B. Malinin, senior scientist of Central Research Institute No. 45, and a group of the staff of Central Designing Bureau No. 18, for designing a new type of warship; I. Maslennikov, director of the Experimental Research Institute for Metal-Cutting Machine Tools, and a group of the staff of the Bureau for Machine Tool Aggregates of the same Institute, for designing new highly efficient machine tools for war industry; N. Polikarpov, aircraft designer, for designing a now model of warplane. N. Rubtsov, Moscow "Baumann" Machine Building Institute, and a group of engineers and staff members, for improvement in the technology 
of ammunition production; P. Sukhon, aircraft designer, for designing a new type of warplane; A. Tupolev, aircraft designer, for the creation of a new type of warplane; A. Charomsky, aircraft engine designer, for a new type of aircraft engine. A group of workers of Works Nos. 231, 659, 389, 702, for designing a new type of naval armament; $\mathbf{A}$. Shevtsov, aircraft engine designer, for designing a new type of aircraft engine; A. Yakovlev, aircraft designer, for modification and improvement of warplanes.

\section{FORTHCOMING EVENTS}

\section{Saturday, April 10}

Assoctation OF UNIVERSTTY Professors aNd LeCturars OF THB ALIIED COUNTRIES IN GREAT BRITAIN (at the Royal Institution, 21 Albemarle Street, Piccadilly, London, w.1)-Educational Conference. At 10 a.m.- "The Function of a University in a Modern Community" at 2.30 p.m.- "Methods of Practical Co-operation between Allied Universities in the Future".

Saturday, April 10-Sunday, April II

INSTTTUTE OF PUBLIC ADMINISTRATION (JOINT MEETING WITH THE INSTITUTE OF INDUSTRIAL ADMINISTRATTON AND THE METROPOLITAN AREA EDUCATION COMMITTEE OF THE NATIONAL ASSOCLATION OF LOCAL GOVERNMENT OFFICERS) (in the County Hall, Westminster, tion-the Need for an Administrative Staff College".

Saturday, April 10

2.30 p.m.-Discussion to be opened by Mr. E. S. Byng.

Sunday, April II

10.30 a.m.-Discussion to be opened by Prof. Harold J. Laski.

Thursday, April 8-Monday, April 12

British Psychologicat SocimTy (in the Debating Hall of the Union Society, Oxford).-Extended General Meeting.

Thursday, April 8

8.30 p.m.-Prof. C. Burt: "British Psychology in War-time"' (Presidential Address).

Saturday, Aprit 10

Symposium on "Mental Attitudes in Time of War".

9.30 a.m.-Dr. R. H. Thouless: "Hatred of the Enemy".

10 a.m.-Prof. T. H. Pear: "Psychological Implications of "Reducating the Germans" '.

10.30 a.m.-Mr. Ranyard West: "What are we to Think ?"

Monday, April 12

RoYaI Geographical SocirTy (at Kensington Gore, London, S.W.7), at 8 p.m.-Dr. Raymond Firth: "The Coastal People of Kelantan and Trengganu, Malaya".

\section{Tuesday, April 13-Wednesday, April 14}

Soctexy of GLASs TEChNOLOGY (at Elmfleld, Northumberland Road, Sheffield 10).-Annual General Meeting, and Conference on "Education, Technical Training and Research for Post-War Developments in the Glass Industry".

\section{Wednesday, April 14}

ROYAI SOCIETY OF ARTS (at the Institution of Electrical Engineerg, Savoy Place, Victoria Embankment, London, W.C.2), at 1.45 p.m.Mr. J. G. Crowther: "Science in Soviet Russia" (Trueman Wood Lecture).

BRITISH SOCIETY FOR INTERNATIONAL BIBLIOGRAPHY (at the Science Museum, Exhibition Road, South Kensington, London, S.W.7), at Museum, Exhibition Road, South Kensington, London, S.W.7), at Literature and Records", ; Mr. C. E. Lee: "Documentation in the Transport Industry".

ROYal Colleg of SURGEONs of ENGLAND (at Inncoln's Inn Fields, London, W.C.2), at 4 p.m.-Prof. C. Raymond Greene : "Frost-Bite and Kindred Conditions" (Hunterian Lecture).

Thursday, April 15

Chracrcal Society (at Burlington House, Piccadilly, London, W.1), at 2.30 p.m.-Prof. S. Sugden, F.R.S.: "Magnetochemistry" (Ninth Liversidge Lecture)

INsmitumion of NAVAT AROHIFETS (at the Royal Society of Arts John Adam Street, Adelphi, London, W.C.2), at 2.30 p.m.-Annual General Meeting ; at 3 p.m.-Dr. G. D. Bengough, F.R.S., and Mr. v. G. Shepheard: "Fouling and Corrosion of Ships"; at 4.15 p.mMr. R. W. L. Gawn: "Steering Experiments", Part 1.
Friday, April 16

INSTITUTION OF ELECTRICAI ENGINEERS (MEASUREMENTS SECTION) (at Savoy Place, Victoria Embankment, London, W.C.2), at 3 p.m.Mr. A. R. Dunton: "The Control, Specialized Testing and Use of some Modern Insulating Materials"'

\section{Saturday, April 17}

BRITISH Rheologists' ClUb (JoINT MEeTINe With the MaNChester AND DISTRICT SECTION OF THE INSTITUTE OF THE RUBBER INDUSTRY) (at the Engineers" Club, Albert Square, Manchester), at 10 a.m.
Discussion on "The Rheology of Rubber and Rubber-like Materials" (Chairman : Mr. W. N. Lister).

\section{APPOINTMENTS VACANT}

APPLICATIONS are invited for the following appointments on or before the dates mentioned :

DISTRICT OFFICER, and AssistaNT DISTRICT OFFICERS, to the Somerset War Agricultural Executive Committee-The Executive Officer, Parklands, Trull Road, Taunton (April 14).

Edvcational Psychologist-The Secretary-Superintendent, Belfast Hospital for Sick Children, Belfast (April 15).

Educational Psychologist-The Secretary, County Education Offices, Castle Street, Exeter (April 16).

LECTURER IN CIVIL ENGINEERINa at the Brighton Technical College -The Education Officer, 54 Old Steine, Brighton 1 (April 16).

PrincIPal for the Whitwood Mining and Technical CollegeMr. M. G. Swaine, Education Offlces, 97 Smawthorne Lane, Castleford, Yorks. (April 17).

Teacher to take Practical Geometry in the Manchester School of Bullding -The Director of Education, Education Offices, Deansgate, Manchester (April 17).

Psychologrst at the Child Guidance Clinic-The Secretary for Education, 6 Lampton Road, Hounslow (April 17).

TeChNical Assistant, ChIEFly For CULtivation and CROPPINGThe Executive Officer, Holland War Agricultural Executive Committee, 15 Market Place, Boston, Lines. (April 17).

Teacher for Generai Science, Preferably Chemistry, Physics AND SOME BIOLOGY, at the Southend-on-Sea Municipal College-The Chief Education Officer, Education Office, Warrior Square, Southendon-Sea (April 21)

HEAD OF THE ELECTRICAI ENGINERRING DEPARTMENT of the Rutherford Technical College-The Director of Education, City Education Office, Northumberland Road, Newcastle-upon-Tyne 2 (April 29).

INSTRUCTOR FOR TRAINING RADIO MECHANICS, WITH GOOD QUALIFICATIONS IN THEORY AND PRACTICE OF RADIO WORK, AND A LECTTRER in Mechanical Engingering, at the Rugby College of Technology and Arts-The Organizer of Further Education in Rugby, Rugby (April 30)

Lecturer in Electrical Enginaming-The Principal and Secretary, Harris Institute, Preston.

Assistant ENGINEER for the Georgetown Sewerage and Water Commissioners, British Guiana-The Secretary, Overseas Manpower Committee (Ref. 352), Ministry of Labour and National Service Sardinia Street, Kingsway, London, W.C.2.

SPEECH THERAPIST-The Acting Director of Education, Education Offices, Becket Street, Derby.

IRRIGATION ENGINEER for the Irrigation Department, Government of Ceylon-The Secretary, Overseas Manpower Committee (Ref, 775), Ministry of Labour and National Service, Sardinia Street, Kingsway, London, W.C.2.

Assistant Enginear for the British Guiana Public Works Department-The Secretary, Overseas Manpower Committee (Ref. 767), Ministry of Labour and National Service, Sardinia Street, Kingsway, London, W.C.2.

\section{REPORTS and other PUBLICATIONS}

\section{(not included in the monthly Books Supplement)}

\section{Great Britain and Ireland}

British Trade Unionism: a Short Study Course for Scientiflc Workers. Prepared by J. Kuczynski and a Study Group of the Central London Branch of the Association of Scientific Workers. Pp. 44. (London: Association of Scientific Workers.) 18. ${ }^{2222}$ Chemistry and the Petroleum Industry. By Dr. A. E. Dunstan. Pp.
48. (London: Institute of Chemistry.)

Hannah Dairy Research Institute. Bulletin No. 8: The Production of Artiflcially Dried Grass. By Dr. James McNair in association with Dr. Alexander B. Fowler. Pp. 11i. (Kirkhill, Ayr : Hannah Dairy
Research Institute.)

How to Keep Well in Wartime. By Dr. H. A. Clegg. (Issued for the Ministry of Health by the Ministry of Information.) Pp. 24. (London H.M. Statíonery Office.) $3 d$. net. [242 Jamaica Constitution. Despatch from the Secretary of State for
he Colonies to the Governor of Jamalcs, dated 10th February 1943 . (Cmd, 6427.) Pp. 14. (London: H.M. Stationery Office.) $3 d$. net. [252 